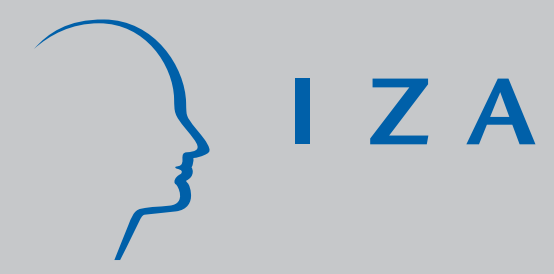

IZA DP No. 3420

Labor Market Outcomes of Immigrants and Non-Citizens in the EU: An East-West Comparison

Martin Kahanec

Anzelika Zaiceva

March 2008 


\title{
Labor Market Outcomes of Immigrants and Non-Citizens in the EU: An East-West Comparison
}

\author{
Martin Kahanec
}

IZA

Anzelika Zaiceva

University of Bologna

and IZA

Discussion Paper No. 3420

March 2008

\author{
IZA \\ P.O. Box 7240 \\ 53072 Bonn \\ Germany \\ Phone: +49-228-3894-0 \\ Fax: +49-228-3894-180 \\ E-mail: iza@iza.org
}

\begin{abstract}
Any opinions expressed here are those of the author(s) and not those of IZA. Research published in this series may include views on policy, but the institute itself takes no institutional policy positions.

The Institute for the Study of Labor (IZA) in Bonn is a local and virtual international research center and a place of communication between science, politics and business. IZA is an independent nonprofit organization supported by Deutsche Post World Net. The center is associated with the University of Bonn and offers a stimulating research environment through its international network, workshops and conferences, data service, project support, research visits and doctoral program. IZA engages in (i) original and internationally competitive research in all fields of labor economics, (ii) development of policy concepts, and (iii) dissemination of research results and concepts to the interested public.
\end{abstract}

IZA Discussion Papers often represent preliminary work and are circulated to encourage discussion. Citation of such a paper should account for its provisional character. A revised version may be available directly from the author. 
IZA Discussion Paper No. 3420

March 2008

\section{ABSTRACT \\ Labor Market Outcomes of Immigrants and Non-Citizens in the EU: An East-West Comparison*}

The starkly different histories and institutions in the eastern and western member states of the European Union (EU) suggest different roles of being non-native in these two regions. In this paper we study the roles of foreign origin and citizenship in the comparative East-West perspective. Our results indicate that while it is immigrant status that is of key importance in the western EU member states, both immigrant status and citizenship matter in the eastern EU member states, their roles depending on gender. We find some evidence that it is the Russian ethnic minority in Estonia and Latvia that drives the relationships between being non-citizen and labor market outcomes that we find in the eastern EU member states.

JEL Classification: F22, J15, J61, J71

Keywords: immigrant, citizenship, earnings, employment, labor market, Eastern Europe

Corresponding author:

Martin Kahanec

IZA

P.O. Box 7240

53072 Bonn

Germany

E-mail: kahanec@iza.org

\footnotetext{
Financial support from Volkswagen Foundation for the IZA project on "The Economics and Persistence of Migrant Ethnicity" is gratefully acknowledged.
} 


\section{Introduction}

How immigrants fare in the Western European labor markets in terms of their earnings, employment, self-employment and other labor market outcomes has been the focus of a large body of literature. A complementary literature looks at residents without the citizenship of the host country. In contrast, the labor market fates of nonnatives ${ }^{1}$ in Eastern Europe have received scarce attention. ${ }^{2}$ Yet, the populations in this region are far from monoethnic and the related labor market issues are far from trivial. This paper evaluates and compares the labor market performance of immigrants and non-citizens in the new eastern member states of the European Union that accessed in 2004 (EU8) to that in the long-standing western EU member states (EU15). ${ }^{3}$

The histories of immigrants and non-citizens in Western and Eastern Europe in the post-war period differ significantly. There has been a large influx of foreign workers and their families into Western European countries since the 1960s, fueled by the need to sustain the post-war economic growth. This inflow has followed postcolonial linkages as in the case of France or the United Kingdom, or new immigration patterns emerged, such as those facilitated by immigrant treaties between the former West Germany and the source countries including Turkey, Morocco, and Yugoslavia. Although some of the immigration channels were discontinued following the 1973 oil

\footnotetext{
${ }^{1}$ We use the term non-native to denote people who are either foreign born or non-citizens. We are well aware of the fact that some non-citizens are not foreign born, however. This is the case for many ethnic Russians in the Baltic States or Guestworkers’ descendants in Germany.

2 The early contributions include Chiswick (1978) and Borjas (1985, 1990, 1995) on the labor market performance of immigrants, Bratsberg, Ragan and Nasir (2002) on the effects of naturalization, Zimmermann (2005) summarizes what we know about Western European immigration, and Constant, Kahanec and Zimmermann (2006a) represents the literature on ethnic minorities in Eastern Europe. We summarize this literature below.

${ }^{3}$ EU8 refers to Czech Republic, Estonia, Hungary, Latvia, Lithuania, Poland, Slovakia, and Slovenia. We do not include Cyprus and Malta into the analysis, since both their historical background and labor market situation is very different form the transition countries. EU15 refers to Austria, Belgium, Denmark, Germany, Greece, Finland, France, Ireland, Italy, Luxembourg, the Netherlands, Portugal, Spain, Sweden, the United Kingdom.
} 
shock, migration continued through family reunification, increased fertility rates, and asylum seekers and refugees. Whether these immigrants have become citizens or not largely depends on the specific legal arrangements in a given country.

In contrast, Central and Eastern Europe, under the yoke of the communist regimes, experienced very little international migration prior to 1990s. However, the Baltic republics of the former Soviet Union, Estonia and Latvia in particular, received substantial inflows of mostly Russian speaking people during the Soviet times that, upon the independence of these countries in 1991, emerged as sizeable immigrant minorities whose members frequently lack citizenship. During the 1990s, the EU8 countries started to receive some inflows of economic immigrants, especially skilled professionals that accompanied the inflows of foreign direct investments. With improving economic conditions and after accession to the EU, the EU8 countries are becoming an even more attractive destination region for migrants from less prosperous countries, predominantly further East in Europe and Asia.

The main question that this paper addresses in a comparative perspective is whether and how these institutional and historical differences manifest themselves in the labor market outcome of non-natives in EU15 and EU8. We do not aspire to evaluate the causal relationships, rather, we highlight the differences in the roles of immigrant and citizenship status in EU15 and EU8 labor markets in a descriptive manner. ${ }^{4}$ In the next section we summarize the literature and then introduce the EU SILC dataset that we use in this study and briefly describe the main features of the native and non-native populations across Europe. We then quantify and compare the effects of being an immigrant or a non-citizen in EU15 and EU8 using standard OLS and Probit models. Finally, we measure the divide engendered by immigrant or

\footnotetext{
${ }^{4}$ The endogeneity of migration and citizenship decisions is well documented; see e.g. Zimmermann (2005) on the former and DeVoretz (2006) on the latter.
} 
citizenship status in EU15 and EU8 labor markets decomposing the raw outcome differentials between native and non-native groups into the part that is explained by observable characteristics and the unexplained part. The latter may reflect discrimination but also differences in ethnic capital or the character of institutional and own selection of non-natives into different countries or citizenship statuses. We then discuss the roles that immigrant status and citizenship play in EU15 and EU8 and provide suggestions for further research.

\section{Related Literature}

The early literature on the position of immigrants in the earnings distribution includes Chiswick (1978) and Borjas (1985, 1990, 1995). Chiswick, Le and Miller (2008) investigate immigrant earnings in an international perspective. Zimmermann (2005) discusses what we know about the European immigrant ethnic minorities. Adsera and Chiswick (2007) scrutinize the gender and country of origin differences in immigrant labor market outcomes across European destinations. The employment gap between immigrants and natives is evidenced e.g. by Amuedo-Dorantes and de la Rica (2007) for Spain and Simpson et al. (2006) and Kahanec and Mendola (2007) for the UK. That immigrant ethnic minorities with the same characteristics as natives typically have lower labor market returns is evidenced by e.g. Van Ours and Veenman (1999) for the Netherlands and Aeberhardt et al. (2007) for France. Constant (2003) discusses immigrant labor market adjustment in France.

As concerns citizenship, Bratsberg, Ragan and Nasir (2002) find positive effects of naturalization on wages in the US. Fougère and Safi (2006) find that naturalization has a strong positive effect on the employment probability of 
immigrants in France. Bevelander (2000), however, finds that naturalization has a negative effect on economic activity in Sweden. For Denmark, Constant and Zimmermann (2005) find no effect of naturalization on the probability to work but a significant positive effect on earnings, conditional on working, in Denmark. For Germany, they find that naturalized immigrants are more likely to work in paidemployment, less likely to go into self-employment, but they earn more in both selfand paid- employment than the non-naturalized ones. Constant (1998) does not find any positive effects on earnings of Guestworkers in Germany, however.

Constant, Kahanec and Zimmermann (2006a) that measures the RussianUkrainian earnings divide in Ukraine is the first study to investigate the role of ethnicity for labor market outcomes in Eastern Europe. ${ }^{5}$ The scarce existing literature on eastern EU members includes Hazans (2007) that examines the differences in earnings and Hazans, Dmitrijeva and Trapenzikova (2007) that analyze the differences in the duration of unemployment between the Latvian majority and nonLatvian (mainly Russian-speaking) minority. Leping and Toomett (2007) investigate the earnings gap for Estonian and Non-Estonian (mainly Russian-speaking) workers in Estonia.

\section{The Data}

The data that we use in this paper comes from the EU Survey of Income and Living Conditions (SILC) for 2005. This is the second wave of the survey that includes for the first time also new EU Member States. This dataset contains a rich set of socioeconomic variables as well as information on immigration and citizenship status for

\footnotetext{
${ }^{5}$ Another study by the same authors investigates the Russian-Ukrainian political divide in Ukraine (Constant, Kahanec and Zimmermann, 2006b).
} 
both old and new EU members, which is crucial for the purpose of our paper. Moreover, in this dataset it is possible to distinguish between EU and non-EU origin of immigrants. ${ }^{6}$

The dependent variables that we analyze in this paper are respondent's employment status and earnings. The former is constructed by the Eurostat according to the number of months spent in employment. The later indicates employee cash or near cash income in Euros per year. We use gross employee earnings in order to mitigate the potential effects of differences in tax systems between the EU15 and EU8 countries. ${ }^{7}$ Our key independent variables are immigration and citizenship statuses measuring whether an individual is foreign-born or possesses citizenship, or not. In a later stage we also distinguish between EU and non-EU origin, since, as opposed to non-EU origin, EU origin might have different implications for the role of citizenship and immigrant status on one's labor market performance in an EU country. The set of independent control variables includes human capital, measured by educational attainment and potential experience and its square, which is calculated depending on the highest educational degree obtained following Adsera and Chiswick (2007). We also control for marital status, household size, presence of children, and health status of the respondent. In addition, earnings equation includes occupation and sectoral dummies.

In the final sample we include individuals between 18 and 64 years old, drop those retired, still in education, disabled or in military service and with missing information on the key explanatory variables. This leaves us with 173,605

\footnotetext{
${ }^{6}$ Unfortunately, more detailed information on the country of origin is not available. In addition, for Estonia, Latvia and Germany non-citizens and immigrants of EU origin are grouped with their non-EU counterparts.

${ }^{7}$ For Spain, Greece, Italy, Latvia and Portugal, where net rather than gross earnings are reported, we used net instead of gross earnings. Auxiliary analysis where we dropped these countries (available upon request) confirms that our results remain robust with respect to using net or gross earnings. As one would expect in countries with progressive taxation, the magnitudes of the corresponding effects for immigrants and non-citizens are somewhat smaller when using net earnings.
} 
observations. In earnings equations we include only those working full-time and include additional industry and occupation controls, reducing the sample to 101,710 observations. We drop Slovenia from the analysis due to lack of data on citizenship. ${ }^{8}$

The summary statistics of the key variables are reported in Table 1. The main observations are that non-immigrant citizens are the group with the highest probability of employment among males and females in EU15, while in EU8 it is immigrant citizens for both genders. Regarding earnings in EU15, immigrant citizens are at the top for both genders, while the lowest earnings are reported by nonimmigrant citizens among males and non-immigrant non-citizens among females. ${ }^{9}$ In EU8, non-immigrant non-citizens are the lowest earners for both genders, however for males it is immigrant citizens who earn most, while for females it is non-immigrant citizens. In each EU15 and EU8, non-immigrant non-citizens are youngest and least experienced and have the highest proportion with secondary education and the lowest proportion with tertiary education (except for females in EU8, for whom it is nonimmigrant citizens who have the lowest proportion with tertiary education and the highest proportion with secondary education). Finally, immigrants have higher proportions with tertiary education than non-immigrants across the board.

\section{Methodology and Results}

In order to evaluate the links between immigrant status and citizenship on the one hand and employment probability on the other hand in EU15 and EU8, we first estimate the Probit binary choice model of the probability to be employed. In a similar

\footnotetext{
${ }^{8}$ We still use EU8 to denote the new EU member states from Central and Eastern Europe and EU6 to denote the same countries except Estonia and Latvia.

${ }^{9}$ One of the main factors driving these results for raw statistics may be the selection of immigrants into the more prosperous states within EU15 and EU8.
} 
comparative framework, we then consider earnings as another measure of labor market outcomes and estimate Mincerian earnings equations using the standard OLS technique. For both employment and earnings we establish whether and how immigrant and citizenship status matters and then disaggregate these effects by immigrants’ EU and non-EU origin.

Table 2 reports the marginal effects from the Probit employment probability models. It is immediately evident from this table that immigrant status rather than lack of citizenship bears a penalty in employment for males and females in EU15 (about 4 and 5 percentage points, respectively). In EU8, in contrast, it is the lack of citizenship that constitutes a barrier to employment for males (4 percentage points) and both immigrant status and citizenship have a negative effect for females (6 and 4 percentage points, respectively). The remaining regressors exhibit anticipated effects.

Table 3 reports analogous OLS models of the determinants of earnings in EU15 and EU8 countries. For males the results are essentially the same as in case of employment: it is immigrant status in EU15 and lack of citizenship in EU8 that matter and negatively affect earnings. In EU15, in particular, citizenship status also bears an earnings penalty, but smaller and less significant than that resulting from the immigration status (4 percent vs. 8 percent, respectively). In EU8 immigrant status has no significant effect on earnings after we control for citizenship.

For females the results are also similar to those for employment in EU8, where both immigrant status and lack of citizenship are disadvantageous (circa 7 and 5 percentage points, respectively). ${ }^{10}$ Interestingly, immigrant status is not associated with lower earnings in the EU15 in a statistically significant way once citizenship has been controlled for. Again, the other regressors exhibit standard effects.

\footnotetext{
${ }^{10}$ Note that the earnings effect of citizenship for females in EU8 is significant at 5.3\%.
} 
The findings above, however, may hide important differences stemming from immigrants’ origin. Distinguishing between EU and non-EU origin yields several important results. Table 4 decomposes the effects of non-nativity for these two groups, reporting marginal effects of immigrant status and non-citizenship in models corresponding to those in Tables 2 and 3. In addition, we also report the analogous results for the EU6 countries, i.e. those new member states that do not have a significant Russian ethnic minority. ${ }^{11}$

We observe that being an immigrant from a non-EU country is associated with lower employment probability for both males and females in EU15 but only for females in the new member states. Being an EU immigrant is negatively associated with employment for males in EU15 and females in the new member states. Besides the traditional explanations based on discrimination, selection, or similar arguments, the latter finding is also consistent with the hypothesis of internal and external employment barriers faced by the wives, as dependant migrants, of the predominantly male high-skilled EU expatriates working for Western multinationals in Eastern Europe. In EU15 the point estimates of being an EU immigrant are of smaller magnitude than those for non-EU immigrants. In the new member states the opposite is true for females, males exhibiting nonsignificant effects. Both male and female non-citizens from a non-EU country fare significantly worse than natives in EU8. Since this effect disappears in EU6 (and is not present in EU15), we can conjecture that it is driven by the ethnic Russian non-citizens in Estonia and Latvia. ${ }^{12}$ Being a non-citizen of EU origin seems to be harmless for employment, except for females in

\footnotetext{
${ }^{11}$ Czech Republic, Hungary, Lithuania, Poland, Slovakia. The two countries with large ethnic Russian populations are Estonia and Latvia (according to the CIA World Facts Book (www.cia.gov), Russian minority constitutes 25.6 percent in Estonia (in 2000), 29.6 percent in Latvia (in 2002) and only 6.3 percent in Lithuania (in 2001).

${ }^{12}$ Recall that in Estonia and Latvia non-citizens and immigrants of EU origin are grouped with their non-EU counterparts.
} 
EU15, possibly indicating the sluggish adjustment of second generation immigrants (to the extent that this category involves native-born non-citizens).

As concerns earnings, being a non-EU immigrant has a negative correlation with earnings for males in EU15 and for females in EU8. ${ }^{13}$ Male EU immigrants seem to have an advantage in EU8 and EU6 countries; however, the effect is significant only at 10 percent level. This result is consistent with the hypothesis of highly skilled male EU expatriates working for subsidiaries of Western multinationals mentioned above. Lack of citizenship is again negatively associated with earnings for both males and females of non-EU origin in EU8, but not in EU6 or EU15 countries. Similarly as in the case of employment, this result is probably driven by the ethnic Russian noncitizens in Estonia and Latvia. Finally, non-citizens of EU origin have lower earnings in EU15, consistent with the hypothesis of sluggish adjustment of second generation immigrants as in the case of employment.

To summarize this evidence, we find that it is especially immigrant status that matters for both employment and earnings of males and employment of females in EU15. Looking at immigrants’ origin it turns out that these effects are predominantly driven by non-EU immigrants. Females, however, exhibit different patterns as concerns their earnings profiles in EU15. In particular, it is the lack citizenship for females of EU origin that bears an earnings penalty. In EU8 the situation is starkly different for both genders. Namely, it is the lack of citizenship of people of non-EU origin that significantly impairs both employment and earnings. For females an additional story is that immigration status is negatively associated with labor market outcomes, EU origin being more detrimental to employment and non-EU origin to earnings. All the effects for people with non-EU origin found in EU8 become

\footnotetext{
${ }^{13}$ These results for EU15 are consistent with those of Adsera and Chiswick (2007).
} 
insignificant or much less significant if we drop countries with substantial Russian ethnic minorities. This points at the significant role of these minorities in driving the role of immigrant and citizenship status in EU8.

\section{The Measured Labor Market Divide}

In the analysis above we have assumed that the structural labor market relationships are the same for all native and non-native groups. We relax this assumption here and estimate a Fairlie decomposition of employment probabilities (Fairlie, 2005) and an Oaxaca-Blinder decomposition of earnings differentials (Oaxaca, 1973; Blinder, 1973) using the Neumark (1988) method. Namely, for the latter, we decompose earnings differentials between pairs of native and non-native groups as follows:

$$
y^{A}-y^{B}=\underbrace{\Delta x \beta^{p}}_{E X}+\underbrace{\left[x^{A}\left(\beta^{A}-\beta^{p}\right)+x^{B}\left(\beta^{p}-\beta^{B}\right)\right]}_{U N},
$$

where $x$ represents a vector of individual characteristics, $y$ denotes earnings, $\beta$ is a vector of coefficients. Superscript $p$ denotes vectors of coefficients $\beta$ obtained from the pooled model, while superscripts $A$ and $B$ indicate vectors of coefficients from the respective group-wise models. $E X$ and $U N$ mark the explained and unexplained parts of the differential between $y^{A}$ and $y^{B}$, respectively. The Fairlie decomposition decomposes binary outcome employment differentials in the same spirit. We limit our attention to males, since their labor market outcomes are less sensitive to the selection issues related to females' labor market participation decision. ${ }^{14}$

\footnotetext{
${ }^{14}$ Note that some of the results in the decomposition analyses are based on relatively small samples. Nevertheless, as discussed below, they are consistent with the Probit and OLS analysis of the previous sections.
} 
From Table 5 we see that being and immigrant bears an employment penalty beyond differentials in characteristics of about 3.5 to 5.1 percentage points vis-à-vis all other categories in EU15. Being a non-citizen does not bear considerable penalty within the immigrant or non-immigrant categories. In EU8 being an immigrant citizen implies an employment premium of about 10.5 percentage points with respect to nonimmigrant non-citizens. Interestingly, being a non-citizen is associated with a penalty of 12.0 percentage points within the category of non-immigrants and 4.2 percentage points within the category of immigrants. These results confirm the penalty associated with immigrant status in EU15 and the negative role of non-citizenship in EU8 revealed by the Probit model. They further support the hypothesis that the effects in EU8 are largely due to the Russian non-citizens in Estonia and Latvia. First, there are very few non-immigrant non-citizens in EU8 except for Estonia and Latvia. Second, Fairlie decomposition for EU6 reverses the result on the negative role of noncitizenship for immigrants. $^{15}$

Table 6 draws an interesting picture about earnings differentials. In EU15 noncitizens have superior characteristics vis-à-vis citizens and the same holds for immigrants vis-à-vis non-immigrants. In EU8, on the other hand, non-citizens have significantly worse characteristics than citizens, within immigrant and non-immigrant categories. Even more significantly than in EU15, however, immigrants have superior characteristics vis-à-vis non-immigrant non-citizens. Besides human capital differentials, these results may be due to concentration of non-native categories in certain countries.

The unexplained parts of earnings differentials measure the penalty for immigrant status or non-citizenship in the labor market. In EU15, being in any non-

\footnotetext{
${ }^{15}$ Results for EU6 available upon request.
} 
native category bears an earnings penalty vis-à-vis non-immigrant citizens. The estimated effects are considerably more significant for immigrants rather than nonimmigrants and virtually invariant with the citizenship status within the immigrant category, confirming our OLS results that it is mainly immigrant status that matters in EU15. The immigrant penalty signifies the role of discrimination, differences in ethnic capital, selection, or imperfect transferability of immigrants' human capital in Western Europe. In EU8, being a non-citizen is negatively associated with earnings within immigrant category beyond what observable characteristics can explain. The same result, albeit non-significant, holds within the non-immigrant category. Furthermore, being non-immigrant non-citizen bears an earnings penalty vis-à-vis immigrant citizens. While these results are barely significant, they are consistent with our findings from the OLS analysis that it is mainly citizenship that matters in EU8. Insignificant results in a similar decomposition for EU6 countries confirm that the observed effects for EU8 are mainly driven by Estonia and Latvia with significant Russian ethnic minorities. ${ }^{16}$ That being an immigrant non-citizen bears an earnings premium vis-à-vis non-immigrant citizens reiterates the hypothesis of high-skill Western expatriates.

\section{Conclusions}

In this paper we have mapped and compared the roles of foreign origin and citizenship for labor market performance in eastern and western EU member states. While our ambition was not to identify causal relationships, we have shown that these roles are different in these two regions. In EU15 it is essentially immigrant status that

\footnotetext{
${ }^{16}$ Results for EU6 available upon request.
} 
bears a penalty in the labor market, both in terms of employment and earnings and for both genders. In EU8 labor markets citizenship is a key determinant of earnings and employment, especially for males. The evidence for females substantiates the importance of citizenship for labor market outcomes in EU8, but we also find that immigrant status is at least as important for females.

Distinguishing between EU and non-EU origin, our findings confirm the important role of immigrants' background. Moreover, our evidence suggests that the effects of immigrant status and gender in EU8 may be driven by the Russian ethnic minority in Estonia and Latvia. Thus, according to our results, ethnic Russians who are deprived of citizenship in these countries are a particularly vulnerable group in the labor market. Further analysis is necessary to evaluate the causal relationships of immigrant status and citizenship in EU8, focusing in particular on ethnic Russians in Estonia and Latvia. 


\section{References}

Adsera, A./B.R. Chiswick (2007), Are There Gender and Country of Origin Differences in Immigrant Labor Market Outcomes Across European Destinations?, Journal of Population Economics, 20: 495-526.

Aeberhardt, R./D. Fougère/J. Pouget/R. Rathelot (2007), Wages and Employment of Second-Generation Immigrants in France, mimeo, CREST-INSEE, Paris.

Amuedo-Dorantes, C./S. de la Rica (2007), Labour Market Assimilation of Recent Immigrants in Spain, British Journal of Industrial Relations, 45: 257-284.

Bevelander, P. (2000). Immigrant Employment Integration and Structural Change in Sweden:1970-1995. Lund Studies in Economic History 15. Lund: Lund University Press.

Blinder, A. S. (1973), 'Wage Discrimination: Reduced Form and Structural Estimates', Journal of Human Resources, 8: 436-455.

Borjas, G. J. (1985). 'Assimilation, Changes in Cohort Quality, and the Earnings of Immigrants', Journal of Labour Economics, 3: 463-489.

Borjas, G.J. (1990). Friends or Strangers: The Impact of Immigrants on the US Economy. New York: Basic Books.

Borjas, G.J. (1995). 'Assimilation and Changes in Cohort Quality Revisited: What Happened to Immigrant Earnings During the 1980s? ' Journal of Labour Economics, 13: 201-245.

Bratsberg, B/J. F. Ragan/Z. M. Nasir (2001). The Effect of Naturalization on Wage Growth: A Panel Study of Young Male Immigrants, Journal of Labor Economics. 20: 568-597. 
Chiswick, B. R. (1978). 'The Effect of Americanization on the Earnings of ForeignBorn Men'. Journal of Political Economy, 86: 897-921.

Chiswick, B. R./A. T. Le/P. W. Miller (2008). 'How Immigrants Fare Across the Earnings Distribution: International Analysis'. Industrial and Labor Relations Review, 61: 352-373.

Constant, A. (1998). The Earnings of Male and Female Guestworkers and their Assimilation into the German Labor Market: A Panel Study 1984-1993, Ph.D. Dissertation, Vanderbilt University.

Constant, A. (2003). Immigrant Adjustment in France and Impacts on Natives, in: K.F. Zimmermann (Ed.), European Migration: What Do We Know? Oxford, 2005, 263-302.

Constant, A./K. F. Zimmermann (2005). Legal Status at Entry, Economic Performance, and Self-employment Proclivity: A Bi-national Study of Immigrants, IZA DP 1910.

Constant. A./M. Kahanec/K. F. Zimmermann (2006a). The Russian-Ukrainian Earnings Divide, IZA Discussion Paper 2330.

Constant. A./M. Kahanec/K. F. Zimmermann (2006b). The Russian-Ukrainian Political Divide, IZA Discussion Paper 2530.

DeVoretz, D. J. (2006), The Economics of Citizenship: A Common Intellectual Ground for Social Scientists?, IZA Discussion Paper No. 2392.

Fairlie, R. W. (2005), 'An Extension of the Blinder-Oaxaca Decomposition Technique to Logit and Probit Models', Journal of Economic and Social Measurement, 30: 305-316.

Fougère, D./M. Safi (2006). The Effects of Naturalization on Immigrants’ Employment Probability, France 1968-1999, Mimeo. 
Hazans M. (2007), Coping With Growth and Emigration: Latvian Labor Market Before and After EU Accession, Available at SSRN: http://ssrn.com/abstract=971198.

Hazans M./J. Dmitrijeva/I. Trapeznikova (2007), Determinants of unemployment duration in Latvia, Research report to the Ministry of Welfare prepared for the project Reasons and duration of unemployment and social exclusion of the National Programme of Labour Market Studies.

Kahanec, M./M. Mendola (2007), Social Determinants of Labor Market Status of Ethnic Minorities in Britain, IZA Discussion Paper No. 3146.

Leping, K.-O./O.-S. Toomet (2007). Ethnic Wage Gap and Political Break-Ups: Estonia during Political and Economic Transition, Tartu University Working Paper 53.

Neumark, D. (1988), 'Employers' Discriminatory Behavior and the Estimation of Wage Discrimination', Journal of Human Resources, 23: 279-295.

Oaxaca, R. (1973), 'Male-Female Wage Differentials in Urban Labor Markets', International Economic Review, 14: 693-709.

Simpson, L./K. Purdam/A. Tajar/E. Fieldhouse/V. Gavalas/M. Tranmer/J. Pritchard/D. Dorling (2006). Ethnic Minority Populations and the Labour Market: An Analysis of the 1991 and 2001 Census, DWP Research Report No. 333, London: Department for Work and Pensions.

Van Ours, J/J. Veenman (1999), The Netherlands: old immigrants, young immigration country, IZA Discussion Paper No. 80.

Zimmermann, K.F. (Ed.) (2005), European Migration: What Do We Know?, Oxford/New York. 


\section{Tables}

Table 1: Summary statistics

\begin{tabular}{|c|c|c|c|c|c|c|c|c|}
\hline & \multicolumn{4}{|c|}{ EU15 } & \multicolumn{4}{|c|}{ EU8 } \\
\hline & \multicolumn{2}{|c|}{ Non-Immigrants } & \multicolumn{2}{|c|}{ Immigrants } & \multicolumn{2}{|c|}{ Non-Immigrants } & \multicolumn{2}{|c|}{ Immigrants } \\
\hline & Citizens & $\begin{array}{c}\text { Non- } \\
\text { citizens }\end{array}$ & Citizens & $\begin{array}{c}\text { Non- } \\
\text { citizens }\end{array}$ & Citizens & $\begin{array}{c}\text { Non- } \\
\text { citizens }\end{array}$ & Citizens & $\begin{array}{c}\text { Non- } \\
\text { citizens }\end{array}$ \\
\hline & \multicolumn{8}{|c|}{ Males } \\
\hline Employment & 0.931 & 0.922 & 0.900 & 0.909 & 0.867 & 0.827 & 0.892 & 0.870 \\
\hline Experience & 23.371 & 18.058 & 23.139 & 20.406 & 21.959 & 17.929 & 28.402 & 27.413 \\
\hline Age & 42.119 & 36.448 & 42.516 & 39.088 & 40.443 & 36.070 & 47.512 & 46.428 \\
\hline Secondary & 0.615 & 0.700 & 0.596 & 0.510 & 0.787 & 0.811 & 0.735 & 0.713 \\
\hline Tertiary & 0.254 & 0.177 & 0.333 & 0.293 & 0.148 & 0.100 & 0.241 & 0.240 \\
\hline Observations & 60,264 & 243 & 2,212 & 3,366 & 26,023 & 381 & 465 & 537 \\
\hline Log earnings & 9.978 & 10.027 & 10.067 & 10.044 & 8.333 & 8.023 & 8.384 & 8.194 \\
\hline \multirow[t]{2}{*}{ Observations } & 39,406 & 182 & 1,407 & 2,521 & 16,541 & 293 & 313 & 392 \\
\hline & \multicolumn{8}{|c|}{ Females } \\
\hline Employment & 0.894 & 0.860 & 0.858 & 0.873 & 0.852 & 0.871 & 0.876 & 0.843 \\
\hline Experience & 22.337 & 17.465 & 23.254 & 19.181 & 22.000 & 20.827 & 26.976 & 26.812 \\
\hline Age & 41.453 & 35.651 & 42.720 & 38.278 & 40.889 & 39.888 & 46.611 & 46.120 \\
\hline Secondary & 0.595 & 0.680 & 0.585 & 0.512 & 0.731 & 0.691 & 0.650 & 0.687 \\
\hline Tertiary & 0.304 & 0.163 & 0.347 & 0.339 & 0.218 & 0.255 & 0.338 & 0.284 \\
\hline Observations & 49,203 & 172 & 2,029 & 2,661 & 24,664 & 278 & 622 & 485 \\
\hline Log earnings & 9.753 & 9.607 & 9.821 & 9.795 & 8.149 & 7.668 & 8.045 & 7.776 \\
\hline Observations & 22,888 & 100 & 873 & 1,323 & 14,560 & 201 & 388 & 322 \\
\hline
\end{tabular}


Table 2: Employment probabilities

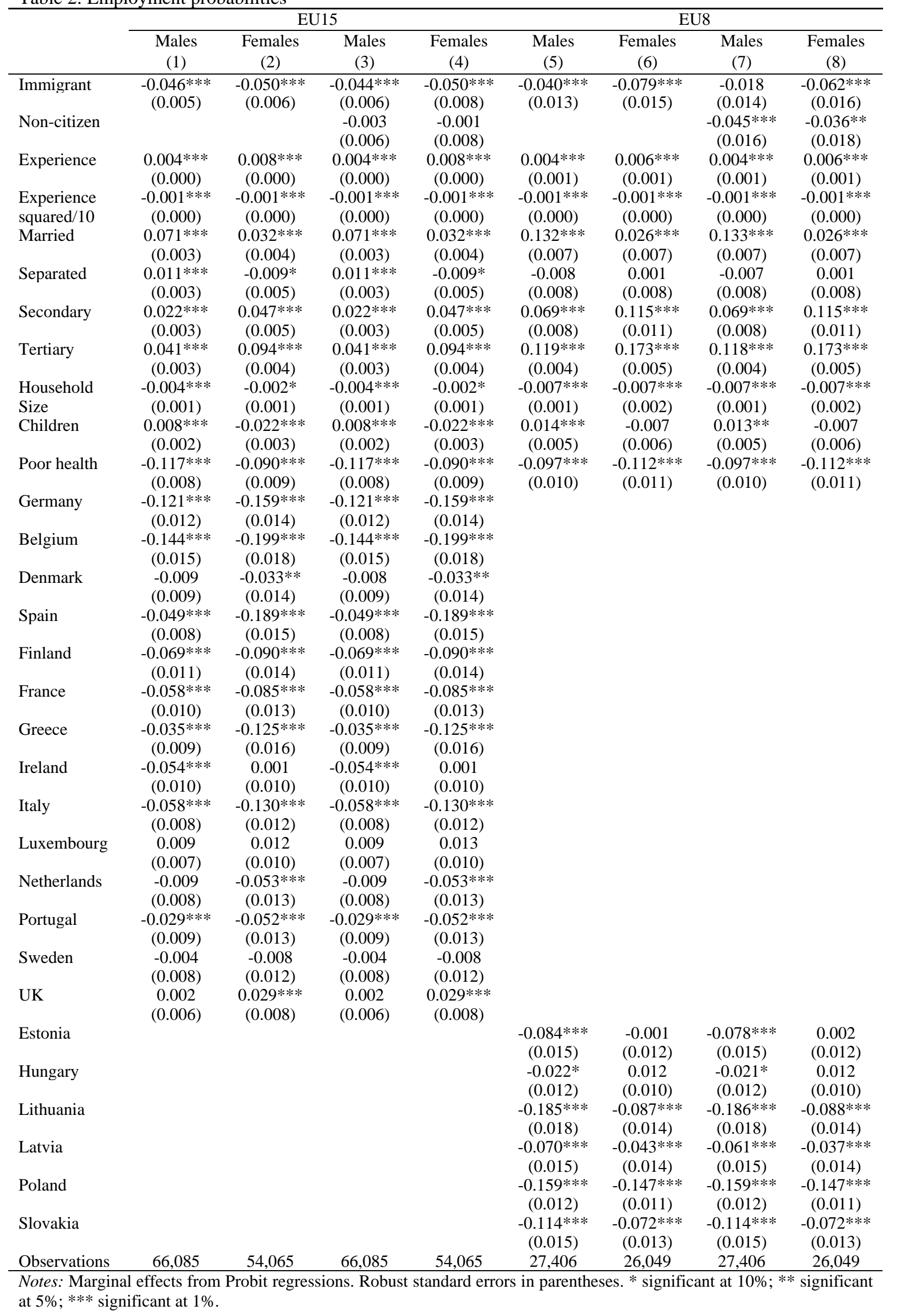


Table 3: Earnings profiles

\begin{tabular}{|c|c|c|c|c|c|c|c|c|}
\hline & \multicolumn{4}{|c|}{ EU15 } & \multicolumn{4}{|c|}{ EU8 } \\
\hline & $\begin{array}{l}\text { Males } \\
\text { (1) }\end{array}$ & $\begin{array}{c}\text { Females } \\
\text { (2) }\end{array}$ & $\begin{array}{c}\text { Males } \\
\text { (3) }\end{array}$ & $\begin{array}{c}\text { Females } \\
\text { (4) }\end{array}$ & $\begin{array}{l}\text { Males } \\
\text { (5) }\end{array}$ & $\begin{array}{c}\text { Females } \\
(6)\end{array}$ & $\begin{array}{c}\text { Males } \\
\text { (7) }\end{array}$ & $\begin{array}{c}\text { Females } \\
(8)\end{array}$ \\
\hline Immigrant & $\begin{array}{c}-0.101^{* * *} \\
(0.010)\end{array}$ & $\begin{array}{c}-0.055^{* * *} \\
(0.015)\end{array}$ & $\begin{array}{c}-0.080 * * * \\
(0.014)\end{array}$ & $\begin{array}{c}-0.020 \\
(0.019)\end{array}$ & $\begin{array}{c}-0.051 * * \\
(0.023)\end{array}$ & $\begin{array}{c}-0.091 * * * \\
(0.021)\end{array}$ & $\begin{array}{c}-0.011 \\
(0.026)\end{array}$ & $\begin{array}{c}-0.069 * * * \\
(0.024)\end{array}$ \\
\hline Non-citizen & & & $\begin{array}{c}-0.036 * * \\
(0.018)\end{array}$ & $\begin{array}{c}-0.066^{* *} \\
(0.026)\end{array}$ & & & $\begin{array}{c}-0.083 * * * \\
(0.030)\end{array}$ & $\begin{array}{c}-0.053^{* *} \\
(0.027)\end{array}$ \\
\hline Experience & $\begin{array}{c}0.054 * * * \\
(0.001)\end{array}$ & $\begin{array}{c}0.049 * * * \\
(0.002)\end{array}$ & $\begin{array}{c}0.054 * * * \\
(0.001)\end{array}$ & $\begin{array}{c}0.049 * * * \\
(0.002)\end{array}$ & $\begin{array}{c}0.036^{* * *} \\
(0.002)\end{array}$ & $\begin{array}{c}0.036 * * * \\
(0.002)\end{array}$ & $\begin{array}{c}0.036^{* * *} \\
(0.002)\end{array}$ & $\begin{array}{c}0.036^{* * *} \\
(0.002)\end{array}$ \\
\hline $\begin{array}{l}\text { Experience } \\
\text { squared/10 }\end{array}$ & $\begin{array}{c}-0.009 * * * \\
(0.000)\end{array}$ & $\begin{array}{c}-0.008 * * * \\
(0.000)\end{array}$ & $\begin{array}{c}-0.009 * * * \\
(0.000)\end{array}$ & $\begin{array}{c}-0.008^{* * * *} \\
(0.000)\end{array}$ & $\begin{array}{c}-0.007 * * * \\
(0.000)\end{array}$ & $\begin{array}{c}-0.006 * * * \\
(0.000)\end{array}$ & $\begin{array}{c}-0.007 * * * \\
(0.000)\end{array}$ & $\begin{array}{c}-0.006 * * * \\
(0.000)\end{array}$ \\
\hline Married & $\begin{array}{c}0.117 * * * \\
(0.008)\end{array}$ & $\begin{array}{c}0.049 * * * \\
(0.010)\end{array}$ & $\begin{array}{c}0.117 * * * \\
(0.008)\end{array}$ & $\begin{array}{c}0.049 * * * \\
(0.010)\end{array}$ & $\begin{array}{c}0.157 * * * \\
(0.015)\end{array}$ & $\begin{array}{l}-0.006 \\
(0.015)\end{array}$ & $\begin{array}{c}0.158 * * * \\
(0.015)\end{array}$ & $\begin{array}{c}-0.005 \\
(0.015)\end{array}$ \\
\hline Separated & $\begin{array}{c}0.040 * * * \\
(0.014)\end{array}$ & $\begin{array}{c}0.013 \\
(0.013)\end{array}$ & $\begin{array}{c}0.041 * * * \\
(0.014)\end{array}$ & $\begin{array}{c}0.013 \\
(0.013)\end{array}$ & $\begin{array}{l}-0.004 \\
(0.023)\end{array}$ & $\begin{array}{c}-0.022 \\
(0.018)\end{array}$ & $\begin{array}{c}-0.003 \\
(0.023)\end{array}$ & $\begin{array}{c}-0.022 \\
(0.018)\end{array}$ \\
\hline Secondary & $\begin{array}{c}0.144 * * * \\
(0.011)\end{array}$ & $\begin{array}{c}0.158 * * * \\
(0.016)\end{array}$ & $\begin{array}{c}0.144 * * * \\
(0.010)\end{array}$ & $\begin{array}{c}0.157 * * * \\
(0.016)\end{array}$ & $\begin{array}{c}0.205^{* * *} * \\
(0.028)\end{array}$ & $\begin{array}{c}0.106 * * * \\
(0.033)\end{array}$ & $\begin{array}{c}0.206 * * * \\
(0.028)\end{array}$ & $\begin{array}{c}0.106 * * * \\
(0.033)\end{array}$ \\
\hline Tertiary & $\begin{array}{c}0.416^{* * *} \\
(0.014)\end{array}$ & $\begin{array}{c}0.387 * * * \\
(0.019)\end{array}$ & $\begin{array}{c}0.416^{* * *} \\
(0.014)\end{array}$ & $\begin{array}{c}0.386 * * * \\
(0.019)\end{array}$ & $\begin{array}{c}0.517 * * * \\
(0.033)\end{array}$ & $\begin{array}{c}0.376 * * * \\
(0.036)\end{array}$ & $\begin{array}{c}0.519 * * * \\
(0.033)\end{array}$ & $\begin{array}{c}0.376^{* * *} \\
(0.036)\end{array}$ \\
\hline $\begin{array}{l}\text { Household } \\
\text { size }\end{array}$ & $\begin{array}{c}-0.018 * * * \\
(0.003)\end{array}$ & $\begin{array}{c}-0.037 * * * \\
(0.004)\end{array}$ & $\begin{array}{c}-0.018 * * * \\
(0.003)\end{array}$ & $\begin{array}{c}-0.037 * * * \\
(0.004)\end{array}$ & $\begin{array}{c}-0.026 * * * \\
(0.004)\end{array}$ & $\begin{array}{c}-0.023 * * * \\
(0.004)\end{array}$ & $\begin{array}{c}-0.026 * * * \\
(0.004)\end{array}$ & $\begin{array}{c}-0.023 * * * \\
(0.004)\end{array}$ \\
\hline Children & $\begin{array}{c}0.022^{* * *} \\
(0.008)\end{array}$ & $\begin{array}{c}-0.038^{* * *} \\
(0.011)\end{array}$ & $\begin{array}{c}0.022^{* * *} \\
(0.008)\end{array}$ & $\begin{array}{c}-0.038^{* * *} \\
(0.011)\end{array}$ & $\begin{array}{l}0.025^{*} \\
(0.013)\end{array}$ & $\begin{array}{c}-0.023^{* *} \\
(0.012)\end{array}$ & $\begin{array}{c}0.023^{*} \\
(0.013)\end{array}$ & $\begin{array}{c}-0.024 * * \\
(0.012)\end{array}$ \\
\hline Poor health & $\begin{array}{c}-0.134^{* * *} \\
(0.022)\end{array}$ & $\begin{array}{c}-0.084^{* * *} \\
(0.022)\end{array}$ & $\begin{array}{c}-0.134 * * * \\
(0.022)\end{array}$ & $\begin{array}{c}-0.084^{* * *} \\
(0.022)\end{array}$ & $\begin{array}{c}-0.101 * * * \\
(0.023)\end{array}$ & $\begin{array}{c}-0.139 * * * \\
(0.021)\end{array}$ & $\begin{array}{c}-0.101 * * * \\
(0.023)\end{array}$ & $\begin{array}{c}-0.139 * * * \\
(0.021)\end{array}$ \\
\hline Germany & $\begin{array}{c}-0.039 * * * \\
(0.014)\end{array}$ & $\begin{array}{c}-0.085 * * * \\
(0.022)\end{array}$ & $\begin{array}{c}-0.039 * * * \\
(0.014)\end{array}$ & $\begin{array}{c}-0.085^{* * *} \\
(0.022)\end{array}$ & & & & \\
\hline Belgium & $\begin{array}{c}0.073 * * * \\
(0.015)\end{array}$ & $\begin{array}{c}0.087 * * * \\
(0.023)\end{array}$ & $\begin{array}{c}0.073 * * * \\
(0.015)\end{array}$ & $\begin{array}{c}0.089 * * * \\
(0.023)\end{array}$ & & & & \\
\hline Denmark & $\begin{array}{c}0.242 * * * \\
(0.020)\end{array}$ & $\begin{array}{c}0.212 * * * \\
(0.027)\end{array}$ & $\begin{array}{c}0.243 * * * \\
(0.020)\end{array}$ & $\begin{array}{c}0.215^{* * * *} \\
(0.027)\end{array}$ & & & & \\
\hline Spain & $\begin{array}{c}-0.578 * * * \\
(0.013)\end{array}$ & $\begin{array}{c}-0.627 * * * \\
(0.020)\end{array}$ & $\begin{array}{c}-0.578 * * * \\
(0.013)\end{array}$ & $\begin{array}{c}-0.625^{* * *} \\
(0.020)\end{array}$ & & & & \\
\hline Finland & $\begin{array}{c}-0.370 * * * \\
(0.027)\end{array}$ & $\begin{array}{c}-0.219 * * * \\
(0.025)\end{array}$ & $\begin{array}{c}-0.370 * * * \\
(0.027)\end{array}$ & $\begin{array}{c}-0.218^{* * *} \\
(0.025)\end{array}$ & & & & \\
\hline France & $\begin{array}{c}-0.154 * * * \\
(0.014)\end{array}$ & $\begin{array}{c}-0.167 * * * \\
(0.021)\end{array}$ & $\begin{array}{c}-0.155^{* * *} \\
(0.014)\end{array}$ & $\begin{array}{c}-0.167 * * * \\
(0.021)\end{array}$ & & & & \\
\hline Greece & $\begin{array}{c}-0.744 * * * \\
(0.015)\end{array}$ & $\begin{array}{c}-0.734 * * * \\
(0.023)\end{array}$ & $\begin{array}{c}-0.744^{* * *} \\
(0.015)\end{array}$ & $\begin{array}{c}-0.733^{* * *} \\
(0.023)\end{array}$ & & & & \\
\hline Ireland & $\begin{array}{c}0.162 * * * \\
(0.016)\end{array}$ & $\begin{array}{c}0.130 * * * \\
(0.024)\end{array}$ & $\begin{array}{c}0.162 * * * \\
(0.016)\end{array}$ & $\begin{array}{c}0.131 * * * \\
(0.024)\end{array}$ & & & & \\
\hline Italy & $\begin{array}{c}-0.475^{* * *} \\
(0.012)\end{array}$ & $\begin{array}{c}-0.422 * * * \\
(0.019)\end{array}$ & $\begin{array}{c}-0.474 * * * \\
(0.012)\end{array}$ & $\begin{array}{c}-0.421 * * * \\
(0.019)\end{array}$ & & & & \\
\hline Luxembourg & $\begin{array}{c}0.397 * * * \\
(0.016)\end{array}$ & $\begin{array}{c}0.374 * * * \\
(0.026)\end{array}$ & $\begin{array}{c}0.405^{* * *} \\
(0.016)\end{array}$ & $\begin{array}{c}0.392 * * * \\
(0.027)\end{array}$ & & & & \\
\hline Netherlands & $\begin{array}{c}0.087 * * * \\
(0.016)\end{array}$ & $\begin{array}{c}0.081^{* * * *} \\
(0.028)\end{array}$ & $\begin{array}{c}0.087 * * * \\
(0.016)\end{array}$ & $\begin{array}{c}0.080 * * * \\
(0.028)\end{array}$ & & & & \\
\hline Portugal & $\begin{array}{c}-0.992 * * * \\
(0.018)\end{array}$ & $\begin{array}{c}-0.932 * * * \\
(0.024)\end{array}$ & $\begin{array}{c}-0.992 * * * \\
(0.018)\end{array}$ & $\begin{array}{c}-0.931 * * * \\
(0.024)\end{array}$ & & & & \\
\hline Sweden & $\begin{array}{c}-0.052 * * \\
(0.021)\end{array}$ & $\begin{array}{c}-0.179 * * * \\
(0.031)\end{array}$ & $\begin{array}{c}-0.052 * * \\
(0.021)\end{array}$ & $\begin{array}{c}-0.179 * * * \\
(0.031)\end{array}$ & & & & \\
\hline UK & $\begin{array}{c}0.109 * * * \\
(0.020)\end{array}$ & $\begin{array}{c}0.120 * * * \\
(0.024)\end{array}$ & $\begin{array}{c}0.108 * * * \\
(0.020)\end{array}$ & $\begin{array}{c}0.121^{* * * *} \\
(0.024)\end{array}$ & & & & \\
\hline Estonia & & & & & $\begin{array}{c}-0.253 * * * \\
(0.018)\end{array}$ & $\begin{array}{c}-0.337 * * * \\
(0.018)\end{array}$ & $\begin{array}{c}-0.245^{* * *} \\
(0.018)\end{array}$ & $\begin{array}{c}-0.334 * * * \\
(0.018)\end{array}$ \\
\hline Hungary & & & & & $\begin{array}{c}-0.267 * * * \\
(0.017)\end{array}$ & $\begin{array}{c}-0.122 * * * \\
(0.018)\end{array}$ & $\begin{array}{c}-0.267 * * * \\
(0.017)\end{array}$ & $\begin{array}{c}-0.122 * * * \\
(0.018)\end{array}$ \\
\hline Lithuania & & & & & $\begin{array}{c}-0.614^{* * *} \\
(0.018)\end{array}$ & $\begin{array}{c}-0.494^{* * *} \\
(0.018)\end{array}$ & $\begin{array}{c}-0.615^{* * *} \\
(0.018)\end{array}$ & $\begin{array}{c}-0.495^{* * *} \\
(0.018)\end{array}$ \\
\hline Latvia & & & & & $\begin{array}{c}-0.717 * * * \\
(0.019)\end{array}$ & $\begin{array}{c}-0.742 * * * \\
(0.019)\end{array}$ & $\begin{array}{c}-0.705^{* * *} \\
(0.020)\end{array}$ & $\begin{array}{c}-0.736 * * * \\
(0.019)\end{array}$ \\
\hline Poland & & & & & $\begin{array}{c}-0.343^{* * *} \\
(0.014)\end{array}$ & $\begin{array}{c}-0.175^{* * *} \\
(0.016)\end{array}$ & $\begin{array}{c}-0.343^{* * *} \\
(0.014)\end{array}$ & $\begin{array}{c}-0.175^{* * *} * \\
(0.016)\end{array}$ \\
\hline Slovakia & & & & & $\begin{array}{c}-0.394 * * * \\
(0.015)\end{array}$ & $\begin{array}{c}-0.381 * * * \\
(0.016)\end{array}$ & $\begin{array}{c}-0.394 * * * \\
(0.015)\end{array}$ & $\begin{array}{c}-0.381 * * * \\
(0.016)\end{array}$ \\
\hline Constant & $9.265 * * *$ & $9.200 * * *$ & $9.266 * * *$ & $9.201 * * *$ & $8.257 * * *$ & $8.232 * * *$ & $8.252 * * *$ & $8.230 * * *$ \\
\hline Observations & 43,516 & 25,184 & 43,516 & 25,184 & 17,539 & 15,471 & 17,539 & 15,471 \\
\hline R-squared & 0.49 & 0.48 & 0.49 & 0.48 & 0.31 & 0.34 & 0.31 & 0.35 \\
\hline
\end{tabular}

Notes: OLS. Robust standard errors in parentheses. * significant at 10\%; ** significant at 5\%; *** significant at $1 \%$. 
Table 4: Marginal effects of immigrants status and citizenship by origin

\begin{tabular}{|c|c|c|c|c|c|c|}
\hline & \multicolumn{2}{|c|}{ EU15 } & \multicolumn{2}{|c|}{ EU8 } & \multicolumn{2}{|c|}{ EU6 } \\
\hline & Males & Females & Males & Females & Males & Females \\
\hline & \multicolumn{6}{|c|}{ Employment } \\
\hline & \multicolumn{6}{|c|}{ Immigrants and non-citizens } \\
\hline Immigrant & $\begin{array}{c}-0.044 * * * \\
(0.006)\end{array}$ & $\begin{array}{c}-0.050 * * * \\
(0.008)\end{array}$ & $\begin{array}{c}-0.018 \\
(0.014)\end{array}$ & $\begin{array}{c}-0.062^{* * *} \\
(0.016)\end{array}$ & $\begin{array}{l}-0.015 \\
(0.020)\end{array}$ & $\begin{array}{c}-0.084 * * * \\
(0.025)\end{array}$ \\
\hline \multirow[t]{2}{*}{ Non-citizen } & $\begin{array}{c}-0.003 \\
(0.006) \\
\end{array}$ & $\begin{array}{l}-0.001 \\
(0.008) \\
\end{array}$ & $\begin{array}{c}-0.045^{* * *} \\
(0.016)\end{array}$ & $\begin{array}{c}-0.036^{* *} \\
(0.018) \\
\end{array}$ & $\begin{array}{l}-0.045 \\
(0.043) \\
\end{array}$ & $\begin{array}{c}0.044 \\
(0.030) \\
\end{array}$ \\
\hline & \multicolumn{6}{|c|}{ Immigrants and non-citizens by region of origin } \\
\hline Non-EU & $-0.053 * * *$ & $-0.071 * * *$ & -0.020 & $-0.048 * * *$ & -0.021 & $-0.048 *$ \\
\hline immigrant & $(0.008)$ & $(0.010)$ & $(0.015)$ & $(0.017)$ & $(0.024)$ & $(0.028)$ \\
\hline EU & $-0.024 * * *$ & -0.010 & -0.003 & $-0.143^{* * *}$ & -0.004 & $-0.153 * * *$ \\
\hline immigrant & $(0.009)$ & $(0.011)$ & $(0.032)$ & $(0.045)$ & $(0.033)$ & $(0.048)$ \\
\hline Non-EU & -0.006 & 0.010 & $-0.043^{* * *}$ & $-0.052 * * *$ & -0.030 & 0.004 \\
\hline non-citizen & $(0.007)$ & $(0.009)$ & $(0.017)$ & $(0.020)$ & $(0.054)$ & $(0.050)$ \\
\hline \multirow{4}{*}{$\begin{array}{l}\text { EU non- } \\
\text { citizen }\end{array}$} & 0.008 & $-0.027 * *$ & -0.056 & $0.071^{*}$ & -0.058 & 0.074 \\
\hline & $(0.008)$ & $(0.014)$ & $(0.060)$ & $(0.030)$ & $(0.062)$ & $(0.033)$ \\
\hline & \multicolumn{6}{|c|}{ Earnings } \\
\hline & \multicolumn{6}{|c|}{ Immigrants and non-citizens } \\
\hline \multirow[t]{2}{*}{ Immigrant } & $-0.080 * * *$ & -0.020 & -0.011 & $-0.069 * * *$ & 0.035 & -0.034 \\
\hline & $(0.014)$ & $(0.019)$ & $(0.026)$ & $(0.024)$ & $(0.035)$ & $(0.044)$ \\
\hline \multirow[t]{3}{*}{ Non-citizen } & $-0.036 * *$ & $-0.066^{* * *}$ & $-0.083 * * *$ & $-0.053 * *$ & -0.019 & 0.046 \\
\hline & $(0.018)$ & $(0.026)$ & $(0.030)$ & $(0.027)$ & $(0.083)$ & $(0.074)$ \\
\hline & \multicolumn{6}{|c|}{ Immigrants and non-citizens by region of origin } \\
\hline Non-EU & $-0.104 * * *$ & $-0.045^{*}$ & -0.040 & $-0.074 * * *$ & 0.005 & -0.020 \\
\hline immigrant & $(0.018)$ & $(0.024)$ & $(0.029)$ & $(0.025)$ & $(0.046)$ & $(0.047)$ \\
\hline EU & -0.028 & 0.020 & $0.094^{*}$ & -0.058 & $0.084^{*}$ & -0.064 \\
\hline immigrant & $(0.022)$ & $(0.027)$ & $(0.050)$ & $(0.083)$ & $(0.051)$ & $(0.084)$ \\
\hline Non-EU & -0.035 & -0.051 & $-0.085^{* * *}$ & $-0.059 * *$ & -0.179 & 0.023 \\
\hline non-citizen & $(0.024)$ & $(0.034)$ & $(0.031)$ & $(0.028)$ & (0.113) & $(0.094)$ \\
\hline EU non- & $-0.050 * *$ & $-0.088 * *$ & 0.146 & 0.086 & 0.136 & 0.073 \\
\hline citizen & $(0.025)$ & $(0.036)$ & $(0.111)$ & $(0.101)$ & $(0.113)$ & $(0.105)$ \\
\hline
\end{tabular}

Notes: Robust standard errors in parentheses. * significant at $10 \%, * *$ significant at $5 \%$, *** significant at 1\%. Econometric models and control variables as in Tables 2 and 3. 
Table 5: The employment divide

\begin{tabular}{|c|c|c|c|c|c|c|c|c|}
\hline & & & \multicolumn{3}{|c|}{ EU15 } & \multicolumn{3}{|c|}{ EU8 } \\
\hline & & & \multicolumn{2}{|c|}{ Non-immigrants } & \multirow{2}{*}{$\frac{\text { Immigrants }}{\text { Citizens }}$} & \multicolumn{2}{|c|}{ Non-immigrants } & \multirow{2}{*}{$\frac{\text { Immigrants }}{\text { Citizens }}$} \\
\hline & & & Citizens & $\begin{array}{c}\text { Non- } \\
\text { Citizens }\end{array}$ & & Citizens & $\begin{array}{c}\text { Non- } \\
\text { Citizens }\end{array}$ & \\
\hline \multirow{3}{*}{$\begin{array}{l}\text { Non- } \\
\text { immigrants }\end{array}$} & \multirow[t]{3}{*}{ Non-citizens } & Difference & -0.010 & & & -0.040 & & \\
\hline & & Explained & -0.012 & & & 0.079 & & \\
\hline & & Unexplained & 0.003 & & & -0.120 & & \\
\hline \multirow[t]{6}{*}{ Immigrants } & \multirow[t]{3}{*}{ Citizens } & Difference & -0.031 & -0.022 & & 0.025 & 0.066 & \\
\hline & & Explained & 0.008 & 0.013 & & 0.013 & -0.039 & \\
\hline & & Unexplained & -0.039 & -0.035 & & 0.012 & 0.105 & \\
\hline & \multirow[t]{3}{*}{ Non-citizens } & Difference & -0.022 & -0.012 & 0.009 & 0.003 & 0.043 & -0.023 \\
\hline & & Explained & 0.029 & 0.028 & 0.026 & 0.014 & 0.039 & 0.020 \\
\hline & & Unexplained & -0.051 & -0.040 & -0.017 & -0.011 & 0.004 & -0.042 \\
\hline
\end{tabular}

Notes: Males. A positive number implies that the row group has a higher employment probability than the respective column group.

Table 6: The earnings divide

\begin{tabular}{|c|c|c|c|c|c|c|c|c|}
\hline & & & \multicolumn{3}{|c|}{ EU15 } & \multicolumn{3}{|c|}{ EU8 } \\
\hline & & & \multicolumn{2}{|c|}{ Non-immigrants } & \multirow{2}{*}{$\frac{\text { Immigrants }}{\text { Citizens }}$} & \multicolumn{2}{|c|}{ Non-immigrants } & \multirow{2}{*}{$\frac{\text { Immigrants }}{\text { Citizens }}$} \\
\hline & & & Citizens & $\begin{array}{c}\text { Non- } \\
\text { Citizens }\end{array}$ & & Citizens & $\begin{array}{c}\text { Non- } \\
\text { Citizens }\end{array}$ & \\
\hline \multirow[t]{3}{*}{$\begin{array}{l}\text { Non- } \\
\text { immigrants }\end{array}$} & Non-citizens & Difference & $\begin{array}{c}0.049 \\
(0.060)\end{array}$ & & & $\begin{array}{l}-0.310 \\
(0.044)\end{array}$ & & \\
\hline & & Explained & $\begin{array}{c}0.126 \\
(0.042)\end{array}$ & & & $\begin{array}{c}-0.256 \\
(0.026)\end{array}$ & & \\
\hline & & Unexplained & $\begin{array}{l}-0.076 \\
(0.042)\end{array}$ & & & $\begin{array}{l}-0.054 \\
(0.039)\end{array}$ & & \\
\hline \multirow[t]{6}{*}{ Immigrants } & Citizens & Difference & $\begin{array}{c}0.089 \\
(0.021)\end{array}$ & $\begin{array}{c}0.040 \\
(0.063)\end{array}$ & & $\begin{array}{c}0.050 \\
(0.039)\end{array}$ & $\begin{array}{c}0.361 \\
(0.058)\end{array}$ & \\
\hline & & Explained & $\begin{array}{c}0.173 \\
(0.014)\end{array}$ & $\begin{array}{c}0.106 \\
(0.048)\end{array}$ & & $\begin{array}{c}0.041 \\
(0.025)\end{array}$ & $\begin{array}{c}0.303 \\
(0.048)\end{array}$ & \\
\hline & & Unexplained & $\begin{array}{l}-0.083 \\
(0.016)\end{array}$ & $\begin{array}{l}-0.066 \\
(0.038)\end{array}$ & & $\begin{array}{c}0.010 \\
(0.032)\end{array}$ & $\begin{array}{c}0.057 \\
(0.032)\end{array}$ & \\
\hline & Non-citizens & Difference & $\begin{array}{c}0.066 \\
(0.017)\end{array}$ & $\begin{array}{c}0.017 \\
(0.062)\end{array}$ & $\begin{array}{l}-0.023 \\
(0.027)\end{array}$ & $\begin{array}{l}-0.139 \\
(0.040)\end{array}$ & $\begin{array}{c}0.171 \\
(0.058)\end{array}$ & $\begin{array}{l}-0.190 \\
(0.055)\end{array}$ \\
\hline & & Explained & $\begin{array}{c}0.163 \\
(0.014)\end{array}$ & $\begin{array}{c}0.060 \\
(0.046)\end{array}$ & $\begin{array}{c}0.030 \\
(0.021)\end{array}$ & $\begin{array}{l}-0.035 \\
(0.024)\end{array}$ & $\begin{array}{c}0.149 \\
(0.041)\end{array}$ & $\begin{array}{l}-0.130 \\
(0.042)\end{array}$ \\
\hline & & Unexplained & $\begin{array}{c}-0.096 \\
(0.011)\end{array}$ & $\begin{array}{l}-0.043 \\
(0.042)\end{array}$ & $\begin{array}{l}-0.007 \\
(0.017)\end{array}$ & $\begin{array}{c}0.104 \\
(0.033)\end{array}$ & $\begin{array}{c}0.022 \\
(0.042)\end{array}$ & $\begin{array}{l}-0.060 \\
(0.036)\end{array}$ \\
\hline
\end{tabular}

Notes: Males. Standard errors in parentheses. A positive number implies that the row group earns more than the respective column group. Log wage differentials are in log points. For EU15 immigrant citizens vs. non-immigrant non-citizens dummies for Ireland and Denmark dropped due to too few observations. 